\title{
Faktor yang Mempengaruhi Kompetensi Pengetahuan IPS Ditinjau dari Disiplin Belajar
}

\section{N.L.W Nopa Suartini*, Ni Ketut Suarni2}

1,2 Universitas Pendidikan Ganesha, Singaraja, Indonesia

\section{ARTICLE INFO}

\section{Article history:}

Received June 25, 2021

Revised June 30, 2021

Accepted July 14, 2021

Available online July 25, 2021

\section{Kata Kunci:}

Disiplin belajar, Kompetensi Pengetahuan IPS

Keywords:

Learning Discipline, Social Sciences Competency

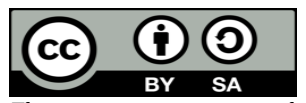

This is an open access article under the $C C$ BY-SA license.

Copyright (C) 2021 by Author. Published by Universitas Pendidikan Ganesha.

\begin{abstract}
A B S T R A K
Kesulitan guru dan orangtua dalam membentuk disiplin belajar anak dapat menyebabkan rendahnya hasil belajar khususnya pada kompetensi pengetahuan IPS siswa. Tujuan penelitian ini adalah untuk mengkaji hubungan antara disiplin belajar belajar dengan kompetensi pengetahuan IPS. Jenis penelitian ini adalah ex post facto. Metode yang digunakan adalah metode tes dan non tes berupa kuesioner tentang disiplin belajar dan kuesioner kompetensi pengetahuan IPS. Populasi penelitian ini merupakan seluruh siswa yang memiliki jumlah sebanyak 42 siswa. Penentuan sampel menggunakan teknik sampling total, dikarenakan jumlah populasi sedikit yaitu kurang dari 100. Variabel bebas dari penelitian ini adalah disiplin belajar sedangkan variabel terikat adalah kompetensi pengetahuan IPS. Data penelitian ini dikomputasi analisis statistik deskriptif dan product moment. Hasil penelitian menunjukkan terdapat hubungan antara disiplin belajar dengan kompetensi pengetahuan IPS siswa dengan perhitungan skor sebesar 3,53 pada taraf signifikansi 5\% dengan kategori korelasi tinggi. Jadi dapat disimpulkan, terdapat arah korelasi positif yang menunjukkan semakin tinggi disiplin belajar semakin meningkat penguasan kompetensi pengetahuan IPS.
\end{abstract}

\section{A B S T R A C T}

The difficulties of teachers and parents in forming children's learning discipline can cause low learning outcomes, especially in students' social science knowledge competencies. The purpose of this study was to examine the relationship between learning disciplines and social studies knowledge competence. This type of research is ex post facto. The methods used are test and non-test methods in the form of questionnaires about learning disciplines and Social Science knowledge competency questionnaires. The population of this research is all students which has a total of 42 students. Determination of the sample using a total sampling technique, because the population is small, which is less than 100. The independent variable of this study is learning discipline while the dependent variable is social science knowledge competence. The data of this study were computed by descriptive statistical analysis and product moment. The results showed that there was a relationship between learning discipline and students' social science knowledge competence with a calculated score of 3.53 at a significance level of 5\% with a high correlation category. So, there is a positive correlation direction which shows the higher the learning discipline, the higher the mastery of social science knowledge competence.

\section{PENDAHULUAN}

Pembelajaran IPS wajib dilakukan pada jenjang sekolah dasar sebagai pondasi dalam membentuk kemampuan sosial yang dimiliki oleh sumber daya manusia kedepannya. Kontribusi guru dan orangtua sangat diperlukan dalam melakukan perbaikan serta inovasi dalam pembelajaran IPS. Pembelajaran IPS diupayakan untuk mengembangkan kompetensi sebagai warga negara yang baik agar dapat menjaga keharmonisan hubungan diantara masyarakat (Alfianiawati et al., 2019; Sukmanasa, 2016; Widodo et al., 2020). Materi pelajaran IPS di sekolah dasar menganut pendekatan terpadu (integrated), artinya materi pelajaran IPS merupakan gabungan dari beberapa disiplin ilmu, namun tidak menunjukan ciri khas dari disiplin ilmu-ilmu sosial tersebut (Azizah, 2021; Erika et al., 2018). Tujuan pembelajaran IPS di sekolah dasar adalah memberikan bekal pengetahuan, nilai dan sikap, ketrampilan, serta disiplin ilmu sosial dalam kehidupan peserta didik di masyarakat, bangsa, dan negara dalam berbagai karakteristik (Diatmika et al., 2017). Sebelum diperolehnya bekal berupa nilai dan sikap serta keterampilan sosial siswa, terlebih dahulu siswa memerlukan penanaman pengetahuan sosial sesuai dengan tahap perkembangan siswa. Tercapainya seluruh tujuan pembelajaran IPS dapat dilakukan dengan penekanan dalam kompetensi pengetahuan dan dalam hal ini tingkat kedewasaan, kematangan, tingkat kompetensi dan pengalaman harus diperhatikan (Fanny, 2018; Hilmi, 2017). Kompetensi pengetahuan IPS merupakan kemampuan pengetahuan siswa yang diukur sebagai hasil pembelajaran IPS berupa pemahaman sosial 
dan hubungan sesama manusia (Parbawa \& Sujana, 2018). Tercapainya kompetensi pengetahuan dalam pembelajaran IPS memerlukan peningkatan kualitas pembelajaran oleh guru dan bantuan berupa bimbingan dari orangtua terhadap anaknya (Anjarsari et al., 2017; Widnyana \& Sujana, 2017).

Namun pada kenyataannya, pembelajaran IPS di SD saat ini masih berpusat pada guru, siswa kurang aktif dalam pembelajaran sehingga pelajaran menjadi membosankan (Fajrin, 2018; Melinda et al., 2017; Rahman, 2017; Romaliyana et al., 2019). Kebosanan siswa dalam pembelajaran karena didominasi guru dalam menyampaikan materi akan berpengaruh terhadap kedisiplinan siswa dalam belajar (Pratiwi \& Fasha, 2015; B. P. Sari \& Hadijah, 2017a). Selain itu, kurangnya kesadaran siswa akan pentingnya disiplin belajar menyebabkan rendahnya hasil belajar siswa khususnya pada kompetensi pengetahuan IPS. Hasil nilai kompetensi pengetahuan IPS memperoleh nilai rata-rata kelas tidak mencapai atau kurang dari KKM (Sulfemi \& Nurhasanah, 2018). Hal ini didukung hasil observasi yang dilakukan di Sekolah Dasar yang menunjukkan bahwa ketika pembelajaran secara daring siswa malas untuk mengikuti proses pembelajaran, kurangnya pengawasan dari guru dan orangtua menyebabkan siswa lebih banyak bermain ketimbang belajar, serta penurunan disiplin belajar siswa yang ditunjukkan dengan keterlambatan siswa dalam mengumpulkan tugas. Kurangnya disiplin belajar siswa ditunjukkan dengan sering terlambat mengikuti pembelajaran, tidak mengerjakan tugas yang diberikan guru, siswa sering tidak serius dalam belajar dan lebih sering memilih melakukan kegiatan yang tidak berhubungan dengan pembelajaran (Nurtia et al., 2017). Apabila hal tersebut tidak segera ditanggulangi, disiplin belajar siswa akan semakin menurun yang akan mempengaruhi rendahnya kompetensi pengetahuan siswa.

Hasil belajar siswa dipengaruhi oleh faktor-faktor yang terdiri dari dua faktor yakni faktor internal dan eksternal. Faktor internal adalah faktor yang berasal dari dalam diri individu yang bersangkutan, yaitu; keadaan fisik dan psikis contohnya seperti disiplin belajar, gaya belajar, motivasi belajar, konsentrasi, rasa percaya diri, intelegensi, kebiasaan belajar, dan lain-lain. Sedangkan faktor eksternal merupakan faktor yang berasal dari luar individu yang bersangkutan atau lingkungannya contohnya keluarga, sarana dan prasarana, kurikulum, dan lain-lain (Sari, 2014). Namun, hal yang paling berpengaruh terhadap hasil belajar siswa khususnya pada kompetensi pengetahuan IPS adalah disiplin belajar siswa (Diatmika et al., 2017; B. P. Sari \& Hadijah, 2017a). Melalui sikap disiplin yang dilakukan oleh siswa akan memudahkan untuk mencapai tujuan, disiplin terhadap waktu akan menjadikan siswa dapat menghargai waktu dan dengan sikap disiplin siswa akan lebih terarah dan teratur, perilaku dan sikap disiplin yang timbul dari dalam dirinya sendiri akan membuat siswa lebih fokus terhadap belajarnya. Siswa yang pandai adalah siswa yang tekun dan memiliki disiplin belajar yang tinggi (Aslianda et al., 2017). Peran orang tua terhadap siswa terkait hasil belajarnya sangat berpengaruh, hal ini dikarenakan perhatian dan sikap disiplin yang diterapkan ke siswa akan menjadikan siswa tersebut akan memberikan dampak terhadap belajarnya, dengan kata lain sikap disiplin siswa terhadap belajarnya tersebut bentuk dari perhatian dan tanggung jawab orang tua. Faktor - faktor disiplin belajar yang mempengaruhi disiplin belajar adalah faktor intrinsik yang didalamnya memuat faktor psikologi seperti minat, bakat, motivasi, konsentrasi dan kemampuan kognitif kemudian faktor fisiologis seperti pendengaran, kesegaran jasmani, keletihan dan kekurangan gizi. Kemudian faktor ekstrinsik atau faktor dari luar yang di dalamnya dipengaruhi oleh faktor sosial seperti lingkungan keluarga, sekolah, dan masyarakat (Sugiarto et al., 2019). Berdasarkan beberapa faktor - faktor tersebut artinya bahwa faktor internal maupun faktor eksternal sangat berpengaruh terhadap disiplin belajar siswa. Secara sederhana, faktor-faktor yang mempengaruhi disiplin belajar siswa adalah faktor keadaan fisik, keadaan psikis, kebiasaan keluarga, penerapan tata tertib sekolah, dan kondisi lingkungan masyarakat (Khafid, 2007; Yuliantika, 2017). Untuk membentuk siswa yang disiplin perlu bantuan pendidikan di sekolah, di rumah, dan di masyarakat maka terbentuk manusia sebagai mahluk sosial yang seutuhnya. Namun apabila salah satu dari ketiga pendidikan tersebut tidak mendukung, maka proses sosialisasi anak akan terhambat, proses belajar juga terhambat dan berpengaruh pula pada terhambatnya hasil belajar IPS siswa (Diatmika et al., 2017). Penelitian yang relevan dengan kajian ini adalah guru masih dihimbau untuk menanamkan disiplin pada siswa, termasuk siswa yang mengulangi pelanggaran yang sama bahkan ketika diingatkan, dan siswa yang mengabaikan peringatan kedisiplinan (Akmaluddin \& Haqqi, 2019). Terdapat korelasi positif yang signifikan antara disiplin belajar siswa terhadap kompetensi pengetahuan IPS siswa (Diatmika et al., 2017). Selain itu dengan menerapkan kedisiplinan siswa dalam belajar siswa akan lebih mampu dalam menyerap pembelajaran yang di berikan serta berdampak positif pada hasil belajarnya (Gultom \& Siahaan, 2016). Selain itu, siswa juga memperoleh hasil, terdapat korelasi positif antara disiplin belajar terhadap hasil belajar siswa (Aslianda et al., 2017; Dewi et al., 2020). Tujuan dari penelitian ini adalah untuk mengkaji hubungan antara disiplin belajar belajar dengan kompetensi pengetahuan IPS. Maka diperlukan suatu kajian mengenai hubungan antara disiplin belajar terhadap kompetensi pengetahuan IPS siswa dalam penelitian yang berjudul "Faktor yang Mempengaruhi Kompetensi Pengetahuan IPS Ditinjau dari Disiplin Belajar". 


\section{METODE}

Penelitian ini diklasifikasin dalam penelitian $E x$ - Post Facto yang mengkaji antara disiplin belajar terhadap kompetensi pengetahuan IPS siswa. Pada penelitian Ex - Post Facto ini melibatkan dua variabel yaitu satu variabel beas dan satu variabel terikat. Variabel bebas adalah disiplin belajar dan variabel terikat adalah kompetensi pengetahuan IPS. Penelitian ini meneliti kejadian alamiah atau fakta yang terjadi dilapangan. Penelitian Ex - Post Facto merupakan pendekatan tanpa suatu perlakuan guna memunculkan variabel yang ingin diteliti pada subjek penelitian (Juniarti et al., 2020; Rizqi \& Sumantri, 2019). Penelitian ini meneliti tentang hubungan sebab - akibat dan penelitian ini juga dilakukan terhadap kejadian yang telah berlangsung tanpa melakukan suatu manipulasi (Pucangan et al., 2017; Sugiartini et al., 2019; Wulandari \& Renda, 2020). Populasi penelitian merupakan keseluruhan objek dalam suatu penelitian yang diukur dengan pengukuran kualitatif maupun kuantitatif pada suatu objek yang lengkap dan jelas kemudian sampel merupakan bagian dari populasi, sampel diambil dan dianggap dapat mewakili populasi tersebut (Koyan, 2012). Populasi dapat memberikan hasil yang relevan pada suatu penelitian. Populasi merupakan suatu subjek atau objek yang mempunyai kualitas dan karakteristik yang diteliti serta diakhir dapat ditarik kesimpulannya (Sugiyono, 2018). Populasi pada penelitian ini sebanyak 42 siswa. Sampel yaitu sebagian dari populasi yang diambil dan dianggap sudah mewakili seluruh jumlah populasi suatu penelitian dan diambil dengan teknik tertentu (Anggraini et al., 2017). Penelitian ini menggunakan teknik sampling total, total pada sampel ini sebanyak 42 sampel.

Metode pengumpulan data pada penelitian ini adalah dengan cara memberikan kuesioner atau angket dengan pernyataan dan pertanyaan di dalamnya. Adapun kisi - kisi hasil validitas instrumen pada disiplin belajar adalah ketaatan terhadap waktu belajar, ketaatan terhadap tugas - tugas pelajaran, ketaatan terhadap penggunaan fasilitas belajar, dan ketaatan menggunakan waktu datang dan pulang. Kisi - kisi hasil validitas instrumen pada kompetensi pengetahuan IPS adalah menjelaskan hasil identifikasi tentang kegiatan ekonomi dan berbagai pekerjaan yang terkait dengan kegiatan ekonomi tersebut di lingkungan sekitar, dan menyajikan hasil identifikasi tentang kegiatan ekonomi dan berbagai pekerjaan yang terkait dengan kegiatan ekonomi tersebut di lingkungan sekitar. Kuesioner ini diberikan kepada siswa Sekolah Dasar. Kuesioner yang digunakan pada penelitian ini menggunakan 2 buah kuesioner yaitu kuesioner disiplin belajar dengan memberikan sebanyak 30 butir pernyataan dan pemberian skornya adalah dengan menggunakan skala likert. Skala likert merupakan skala yang digunakan untuk mengukur persepsi, sikap maupun pendapat seseorang mengenai peristiwa dan fenomena sosial dalam bentuk pertanyaan positif maupun negatif (Pranatawijaya et al., 2019). Selanjutnya kuesioner pada kompetensi pengetahuan IPS siswa tersebut menggunakan sebanyak 30 pertanyaan. Sebelum dilakukannya penyebaran kuesioner kepada responden maka dilakukan uji instrumen terlebih dahulu, pengujian instrumen pada validitas isi dilakukan untuk kedua kuesioner yang akan disebar. Untuk uji validitas isi ini dilakukan dengan melalui penilaian pakar dan kemudian pada penelitian ini pengujian validitas kuesioner diuji dengan menghitung skor hasil kuesioner dan data responden terhadap butir kuesioner dengan menggunakan rumus korelasi product moment dengan kriteria yang digunakan dengan membandingkan $r$ hitung dengan $r$ tabel dengan taraf signifikansi 5\%. Dan kemudian untuk uji reliabilitas instrumen digunakan rumus alpha cronbach.

Teknik analisis data pada penelitian ini menggunakan teknik analisis deskriptif dan teknik analisis inferensial. Dari data analisis deskriptif digunakan rumus mean untuk menghitung rata-rata, median untuk menghitung nilai tengah dan modus serta menghitung standar deviasi. Uji prasyarat analisis yang digunakn pad penelitian ini menggunakan uji normalitas, uji lineritas dan uji hipotesis, uji normalitas pada penelitian ini dilakukan dengan uji chi-square dengan pengambilan keputusan jika signifikasni $>0,05$ maka data berdistribusi normal. Dan uji lineritas data jika nilai signifikansi $>0,05$ maka akan terdapat hubungan antara variabel bebas dan variabel terikat. Serta pengujian hipotesis dilaksanakan untuk mengetahui ada tiaknya hubungan variabel bebas engan variabel terikat dengan menggunakan teknik analisis regresi satu prediktor. Mencari korelasi antara (Y) dengan (X) melalui teknik korelasi product moment.

\section{HASIL DAN PEMBAHASAN}

\section{Hasil}

Secara umum hasil penelitian dideskripsikan pada bagian ini, yaitu berdasarkan hasil pengambilan data disiplin belajar yang memaparkan skor minimum 108 dan skor maksimum 150. Skor rata - rata 133,14, standar deviasi sebesar 11,619 dengan jumlah varians 135,003 sedangkan deskripsi data kompetensi pengetahuan IPS memaparkan jumlah skor maksimum sebanyak 29, skor minimum sebanyak 21. Skor rata - rata 23,36, standar deviasi sebanyak 2,276 dan jumlah varians sebanyak 5,162. Dari data statistik untuk menentukan kelas interval pada penelitian ini dilakukan melalui perhitungan 
tentang sebaran data nilai angket mengenai disiplin belajar dan kompetensi pengetahuan IPS. Uji selanjutnya yang dilakukan adalah uji inferensial untuk mengetahui factor yang mempengaruhi kopenesi IPS. Namuan sebalum dilakukan uaji hipotesisi dialkukan terlebih dahulu uji nomalitas dan uji linieritas. Hasil uji normalitas disiplin belajar menggunakan teknik Chi-Square ( $X^{2}$ ) berbantuan SPSS 20 mendapatkan nilai sebanyak 0,001. Hasil ini menunjukkan lebih kecil dari taraf signifikansi $5 \%(0,05)$ sehingga nilai disiplin belajar siswa dinyatakan normal. Begitu juga untuk uji normalitas pada kompetensi pengetahuan IPS menggunakan teknik Chi-Square $\left(X^{2}\right)$ berbantuan SPSS 20 mendapatkan nilai sebesar 0,003 hasil ini menunjukkan lebih kecil dari taraf signifikansi 5\% maka nilai kompetensi pengetahuan IPS dinyatakan normal. Hasil uji lineritas data disiplin belajar dengan kompetensi pengetahuan IPS menunjukkan hasil nilai Sig Deviation from Linearity $=0,848>0,05$. Dari perolehan data tersebut ditunjukkan bahwa terdapat hubungan yang linier antara variabel disiplin belajar dengan kompetensi pengetahuan IPS. Berdasarkan hasil uji hipotesis yang diketahui bahwa terdapat korelasi yang signifikan antara disiplin belajar dengan kompetensi pengetahuan IPS siswa kelas IV SD Gugus III. Selain itu berdasarkan hasil analisis product moment untuk mengetahui korelasi antara disiplin belajar siswa dengan kompetensi pengetahuan IPS diperoleh hasil $r_{x y}$ sebesar 3,53. Untuk uji signifikansi koefisien korelasi digunakan nilai tabel product moment $\left(\mathrm{r}\right.$ ) untuk $\mathrm{n}$ sebanyak 42 . Nilai $\mathrm{r}_{\text {tabel }}$ untuk $\mathrm{n}=42$ adalah sebesar 0,304 . Maka dinyatakan nilai $r_{h i t u n g}>r_{\text {tabel. }}$. Hal ini menyatakan bahwa nilai $r_{\text {hitung signifikan dengan }}$ nilai 3,53 dan $\mathrm{H}_{0}$ ditolak dan $\mathrm{H}_{\mathrm{a}}$ diterima. Artinya menunjukkan bahwa terjadi korelasi positif yang signifikan antara disiplin belajar dengan kompetensi pengetahuan IPS. Dari hasil analisis analisis dapat dikatakan bahwa terdapat hubungan yang signifikan disiplin belajar dengan kompetensi pengetahuan IPS. Dari hasil ini diperoleh data bahwa korelasi disiplin belajar dengan kompetensi pengetahuan IPS siswa memiliki korelasi atau hubungan yang tinggi karena disiplin belajar tersebut sangat berdampak pada hasil kompetensi belajar siswa, dengan sikap disiplin belajar yang tinggi yang diterapkan siswa maka hasil kompetensi pengetahuan siswa akan baik. Disiplin berasal dari kata yang sama dengan "disciple", dimana seseorang belajar untuk mengikuti seorang pemimpin dengan sukarela. Orang tua dan guru sebagai pemimpin dan anak sebagai pembelajar belajar untuk menjalani kehidupan yang bermakna dan bahagia. Oleh karena itu disiplin adalah cara bagi masyarakat untuk mengajari anak-anak perilaku moral yang disetujui oleh kelompok (Machfiroh et al., 2019). Disiplin juga suatu proses pengajaran, pelatihan, seni pendidikan dan materi kedisiplinan di sekolah, di samping disiplin ini merupakan suatu tindakan sesuai dengan prosedur yang telah ditetapkan. Disiplin berkaitan erat dengan keterampilan siswa di sekolah dan juga dengan pembelajaran (Indrianti et al., 2018).

Disiplin merupakan kesadaran yang membentuk sikap, tingkah dan pola perilaku siswa untuk belajar dengan tertib, teratur, dan penuh tanggung jawab tanpa paksaan dari siapapun (B. P. Sari \& Hadijah, 2017b). Pernyataan ini juga diperkuat oleh Sukardi (dalam Angraini, 2018) bahwa dengan bersikap disiplin dapat menghindari gangguan serta godaan yang ada disekitar. Hasil penelitian ini juga sejalan dengan penelitian sebelumnya, yang mengkaji disiplin belajar dengan hasil belajar IPS yang dilakukan oleh (Diatmika et al., 2017) yang menunjukkan bahwa terdapat korelasi positif yang signifikan antara disiplin belajar dengan hasil belajar IPS siswa kelas V dengan perhitungan nilai sebanyak 2,803 > 1,980. Kemudian penelitian yang serupa juga dilakukan oleh Aslianda et al., (2017) pada hasil penelitian bahwa $\mathrm{H}_{0}$ dinyatakan ditolak sedangkan hipotesis penelitian $\mathrm{H}_{\mathrm{a}}$ dinyatakan diterima. Artinya terdapat korelasi yang positif antara disiplin belajar dengan hasil belajar siswa dengan perhitungan analisis data yang didapatkan nilai sebesar $r_{\text {hitung }} 0,59$ dengan $r_{\text {tabel }}$ 0,361 dengan taraf signifikansi 5\%. Penelitian yang relevan dengan kajian ini adalah guru masih dihimbau untuk menanamkan disiplin pada siswa, termasuk siswa yang mengulangi pelanggaran yang sama bahkan ketika diingatkan, dan siswa yang mengabaikan peringatan kedisiplinan (Akmaluddin \& Haqqi, 2019). Terdapat korelasi positif yang signifikan antara disiplin belajar siswa terhadap kompetensi pengetahuan IPS siswa (Diatmika et al., 2017). Selain itu dengan menerapkan kedisiplinan siswa dalam belajar siswa akan lebih mampu dalam menyerap pembelajaran yang di berikan serta berdampak positif pada hasil belajarnya (Gultom \& Siahaan, 2016). Selain itu, siswa juga memperoleh hasil, terdapat korelasi positif antara disiplin belajar terhadap hasil belajar siswa (Aslianda et al., 2017; Dewi et al., 2020). Tujuan dari penelitian ini adalah untuk mengkaji hubungan antara disiplin belajar belajar dengan kompetensi pengetahuan IPS. Maka diperlukan suatu kajian mengenai hubungan antara disiplin belajar terhadap kompetensi pengetahuan IPS siswa dalam penelitian yang berjudul "Faktor yang Mempengaruhi Kompetensi Pengetahuan IPS Ditinjau dari Disiplin Belajar"

Berdasarkan uraian tersebut, maka siswa yang memiliki disiplin belajar yang tinggi akan dapat meningkatkan kompetensi belajarnya terutama pada penelitian ini. Siswa yang memiliki disiplin belajar yang tinggi akan dapat meningkatkan kompetensi pengetahuan IPS, dari beberapa aspek dan indikator yang dimiliki seperti ketaatan terhadap waktu belajar, ketaatan terhadap tugas - tugas pelajaran, ketaatan terhadap penggunaan fasilitas dan ketaatan terhadap menggunakan waktu datang dan pulang. Sejalan 
dengan pendapat dari Daryanto (dalam Manazila, 2017) sikap disiplin dalam belajar mereka maka akan berdampak pada hasil belajar mereka yang bisa maksimal. dengan sikap disiplin siswa dalam belajar mengingat, memahami dan mengaplikasikan dalam pelajaran makan akan dapat meningkatkan kompetensi pengetahun IPS siswa. Kelebihan dari adanya penelitian ini adalah didapatkannya informasi mengenai disiplin belajar dengan kompetensi pengetahuan IPS siswa sesuai dengan fakta atau fenomena yang terjadi dilapangan, penelitian sejenis mungkin pernah dilaksanakan namun setiap tahunnya akan mengalami pembaharuan dan terdapat berbagai jenis hambatan atau rintangan dalam melaksanakan penelitian tersebut. Dalam penelitian ini sudah memaparkan teori disiplin belajar dengan kompetensi pengetahuan IPS dengan singkat dan jelas selain itu terdapat hasil penelitian beserta pembahasan yang sudah dibahas dengan terperinci, penelitian ini juga dapat dijadikan sebagai pendukung atau rujukan dalam penelitian lain.

\section{SIMPULAN}

Berdasarkan penelitian yang telah dilakukan dapat disimpulkan bahwa terdapat korelasi yang signifikan antara disiplin belajar dengan kompetensi pengetahuan IPS siswa. semakin tinggi disiplin belajar siswa maka semakin meningkat penguasan kompetensi pengetahuan IPS siswa.

\section{DAFTAR PUSTAKA}

Akmaluddin, \& Haqqi, B. (2019). Kedisiplinan Belajar Siswa di Sekolah Dasar ( SD ) Negeri Cot Keu Eung Kabupaten Aceh Besar ( Studi Kasus ). Jurnal Education, 5(2), 1-12. file:///C:/Users/7/Downloads/467-554-1-SM.pdf.

Alfianiawati, T., Desyandri, \& Nasrul. (2019). Pengaruh Penggunaan Model Problem Based Learning terhadap Hasil Belajar Siswa dalam Pembelajaran IPS di Kelas V SD. Ejournal Pembelajaran Inovasi: Jurnal Ilmiah Pendidikan Dasar, 7(3), 1-10.

Anggraini, Hartuti, P., \& Sholihah, A. (2017). Hubungan Pola Asuh Orang Tua Dengan Kepribadian Siswa SMA Di Kota Bengkulu. Consilia: Jurnal Ilmiah Bimbingan Dan Konseling, 1(1), 10-18. https://doi.org/10.33369/consilia.1.1.10-18.

Angraini, L. M. (2018). Pengaruh Concept Attainment Model Terhadap Disposisi Berpikir Kritis Matematis Mahasiswa. JNPM (Jurnal Nasional Pendidikan Matematika), 2(2), 284. https: //doi.org/10.33603/jnpm.v2i2.1473.

Anjarsari, K. Y., Suniasih, N. W., \& Sujana, I. W. (2017). Pengaruh Model Pembelajaran Talking Chips Berbasis Tri Hita Karana Terhadap Kompetensi Pengetahuan Ips. Mimbar PGSD, 5(2).

Aslianda, Z., Israwati, \& Nurhaidah. (2017). Hubungan Disiplin Belajar Terhadap Hasil Belajar SIswa Kelas IV Sekolah Dasar Negeri 18 Banda Aceh. Jurnal Ilmiah Pendidikan Guru Sekolah Dasar.

Azizah, A. A. M. (2021). Analisis Pembelajaran IPS di SD / MI dalam Kurikulum 2013. Journal of Madrasah Ibtidaiyah Education, 5(1), 1-14. https://doi.org/http://dx.doi.org/10.32934/jmie.v5i1.266.

Dewi, I. A. P. Y. P., Yudana, I. M., \& Sanjaya, D. B. (2020). Penerapan Model Pembelajaran Kooperatif Tipe Jigsaw dalam Meningkatkan Hasil Belajar dan Sikap Sosial dalam Mata Pelajaran PPKn PADA Siswa Kelas VIIIB di Smp Negeri 5 Singaraja. Jurnal Media Komunikasi, 2, 218-226. https: //ejournal2.undiksha.ac.id/index.php/JMPPPKn/article/download/150/106/.

Diatmika, I. G. N., Sujana, I. W., \& Putra, M. (2017). Korelasi Antara Disiplin Dalam Belajar Dengan Kompetensi Pengetahuan Ips Siswa Kelas Iv Sd Gugus 1 Kecamatan Mengwi Tahun Pelajaran 2016/2017. Journal of Education Technology. https://doi.org/10.23887/jet.v1i3.12499.

Erika, D., Sumardi, \& Rosarina. (2018). Pengaruh Model Cooperative Learning Tipe Kancing Gemerincing terhadap Hasil Belajar Siswa Pembelajaran IPS di SD. Jurnal Ilmiah Pendidikan Guru Sekolah Dasar, 5(1), 140-152.

Fajrin, O. A. (2018). Pengaruh Model Talking Stick terhadap Hasil Belajar IPS Siswa SD Oktaviastuti Awalia Fajrin PGSD Universitas Kristen Satya Wacana Pendidikan adalah usaha sadar yang dilakukan oleh pendidik untuk mewujudkan suasana belajar dan proses pembelajaran agar pese. Jurnal $\begin{array}{llll}\text { Bidang Pendidikan } & \text { Dasar }\end{array}$ https://doi.org/https: //doi.org/10.21067/jbpd.v2i1A.2353.

Fanny, A. M. (2018). Paradigma Kreativitas Pembuatan Multimedia Pembelajaran IPS Di SD. Buana Pendidikan: Jurnal Fakultas Keguruan Dan Ilmu Pendidikan, 13(23), 1-9. https: //doi.org/10.36456/bp.vol13.no23.a1582.

Gultom, L., \& Siahaan, M. F. (2016). Penerapan Reward dan Konsekuensi untuk Meningkatkan Kedisiplinan Siswa. Polyglot: Journal of Language, Literature, Cullture, and Education, 12(2), 100101. https://doi.org/https://doi.org/10.19166/pji.v12i2.368. 
Hilmi, M. Z. (2017). Implementasi Pendidikan IPS Dalam Pembelajaran IPS Di Sekolah. Jurnal Ilmiah Mandala Education, 3(2), 164-172. https://doi.org/http://dx.doi.org/10.36312/jime.v3i2.198.

Indrianti, R., Djaja, S., \& Suyadi, B. (2018). Pengaruh Motivasi Dan Disiplin Belajar Terhadap Hasil Belajar Mata Pelajaran Prakarya Dan Kewirausahaan. JURNAL PENDIDIKAN EKONOMI: Jurnal Ilmiah Ilmu Pendidikan, Ilmu Ekonomi Dan Ilmu Sosial, 11(2), 69. https://doi.org/10.19184/jpe.v11i2.6449.

Juniarti, N. K. R., Margunayasa, I. G., \& Kusmariyatni, N. (2020). Hubungan Antara Pola Asuh Orang Tua dan Konsep Diri dengan Kompetensi Pengetahuan Matematika Siswa. Jurnal Ilmiah Sekolah Dasar, 4(1), 17. https://doi.org/10.23887/jisd.v4i1.24273.

Khafid, M. (2007). Pengaruh Disiplin Belajar Dan Lingkungan Keluarga Terhadap Hasil Belajar Ekonomi. Jurnal Pendidikan Ekonomi, 2(2), 185-204.

Koyan, I. W. (2012). Statistik Pendidikan Teknik Analisis Data Kuantitatif. Undiksha Press.

Machfiroh, L., Desyanty, E. S., \& Rahmah, R. A. (2019). Pembentukan Karakter Disiplin Anak Usia Dini Melalui Metode Pembiasaan Di Tk Aisyiyah Bustanul Athfal 33 Kota Malang. Jurnal Pendidikan Nonformal V, XIV(1), 54-67. https://doi.org/http://dx.doi.org/10.17977/um041v14i1p54-67.

Manazila, A. (2017). Hubungan Motivasi Belajar dan Disiplin Siswa dengan Hasil Belajar PKn Kelas V. Joyful Learning Journal, 6(1), 61-70.

Melinda, V. A., Degeng, I. N. S., \& Kuswandi, D. (2017). Pengembangan Media Video Pembelajaran Ips Berbasis Virtual Field Trip (VFT) Pada Kelas V SDNU Kraton-Kencong. JINOTEP (Jurnal Inovasi Dan Teknologi Pembelajaran) Kajian Dan Riset Dalam Teknologi Pembelajaran, 3(2), 158-164. https://doi.org/http://dx.doi.org/10.17977/um031v3i22017p158.

Nurtia, W., Ramayani, C., \& Sumarni. (2017). Pengaruh Disiplin Belajar Siswa Fasilitas Belajar Di Sekolah Dan Minat Belajar Terhadap Hasil Belajar Ips Siswa Kelas Viii Smp N 4 Sutera. Journal of Economic and Economic Education, 5(2), 209-216. https://doi.org/10.22202/economica.2017.v5.i2.414.

Parbawa, I. G. N. M. A., \& Sujana, I. W. (2018). Pengaruh Model Pembelajaran Visual Auditory Kinestetik dan Motivasi Belajar Terhadap Kompetensi Pengetahuan IPS Siswa Kelas IV SD Gugus Srikandi Denpasar Timur Tahun Pelajaran 2016/2017. Jurnal Ilmiah Sekolah Dasar, 2(1), 69. https: //doi.org/10.23887/jisd.v2i1.13896.

Pranatawijaya, V. H., Widiatry, W., Priskila, R., \& Putra, P. B. A. A. (2019). Penerapan Skala Likert dan Skala Dikotomi Pada Kuesioner Online. Jurnal Sains Dan Informatika, 5(2), 128-137. https://doi.org/10.34128/jsi.v5i2.185.

Pratiwi, U., \& Fasha, E. F. (2015). Pengembangan Instrumen Penilaian Hots Berbasis Kurikulum 2013 Terhadap Sikap Disiplin. Jurnal Penelitian Dan Pembelajaran IPA, 1(1), 123. https: //doi.org/10.30870/jppi.v1i1.330.

Pucangan, K. Y. J., Suarni, N. K., \& Arini, N. W. (2017). Hubungan antara konsep diri dan pola asuh orang tua terhadap hasil belajar SD kelas II. Jurnal Mimbar PGSD Universitas Pendidikan Ganesha, 5(2), 1-10. https://doi.org/http://dx.doi.org/10.23887/jjpgsd.v5i2.11007.

Rahman, A. (2017). Penerapan Metode Snowball Throwing Untuk Meningkatkan Hasil Belajar IPS Siswa Kelas VII SMP Attaqwa Kabupaten Bekasi. Jurnal Kreatif Online, 5(4), 68-75. https://doi.org/10.31102/wacanadidaktika.6.01.68-75.

Rizqi, A. T., \& Sumantri, M. (2019). Hubungan Antara Motivasi Belajar Dan Pola Asuh Orang Tua Terhadap Hasil Belajar IPA. Jurnal Imiah Pendidikan Dan Pembelajaran, 3(2), 145-154. https://doi.org/http://dx.doi.org/10.23887/jipp.v3i2.18071.

Romaliyana, R. Y., Putra, M., \& Sujana, I. W. (2019). Pengaruh Model Pembelajaran Circuit Learning Berbantuan Media Flipchart Terhadap Kompetensi Pengetahuan Ips Siswa Kelas V. Media Komunikasi FPIPS, 18(1), 22-30. https://doi.org/10.23887/mkfis.v18i1.22235.

Sari, B. P., \& Hadijah, H. S. (2017a). Meningkatkan disiplin belajar siswa melalui manajemen kelas. Jurnal Pendidikan Manajemen Perkantoran, 2(2), 233-241.

Sari, B. P., \& Hadijah, H. S. (2017b). Meningkatkan Disiplin Belajar Siswa melalui Manajemen Kelas ( Improving Students ' Learning Discipline through Classroom Management ). Jurnal Pendidikan Manajemen Perkantoran, 2(2).

Sari, R. I. P. (2014). Hubungan Motivasi Belajar dengan Hasil Belajar Siswa Pada Mata Pelajaran IPS Kelas IV di SDN 11 Petang Jakarta Timur. Pedagogik (Jurnal Pendidikan Sekolah Dasar), II(1), 26-32.

Sugiartini, N. K., Pudjawan, K., \& Renda, N. T. (2019). Hubungan Pola Asuh Orang Tua dan Rasa Percaya Diri Terhadap Hasil Belajar IPA Kelas V. Mimbar PGSD, 5(2), 171. https: //doi.org/10.23887/ika.v17i2.19853.

Sugiarto, A. P., Suyati, T., \& Yulianti, P. D. (2019). Faktor Kedisiplinan Belajar Pada Siswa Kelas X Smk Larenda Brebes. Mimbar Ilmu, 24(2), 232. https://doi.org/10.23887/mi.v24i2.21279

Sugiyono. (2018). Metode Penelitian Kuantitatif. Alfabeta.

Sukmanasa, E. (2016). Hubungan Antara Disiplin Belajar Dengan Hasil Belajar Pada Mata Pelajaran Ilmu 
Pengetahuan Sosial. Jurnal Pendidikan Ekonomi Undiksha, 9(September), 35-44.

Sulfemi, W. B., \& Nurhasanah. (2018). Penggunaan Metode Demontrasi Dan Media Audio Visual Dalam Meningkatkan Hasil Belajar Peserta Didik Mata Pelajaran Ips. Pendas Mahakam: Jurnal Pendidikan Dasar, 3(2), 151-158. https://doi.org/10.31227/osf.io/qrhsf.

Widnyana, I. G., \& Sujana, I. W. (2017). Pengaruh Model Pembelajaran Role Playing Berbasis Tri Hita Karana Terhadap Kompetensi Pengetahuan Ips Kecamatan Denpasar Timur Tahun Pelajaran $\begin{array}{llllll}2016 \text { / 2017. MIMBAR PGSD Undiksha, } & \text { (2) }\end{array}$ https://doi.org/http://dx.doi.org/10.23887/jjpgsd.v5i2.11995.

Widodo, A., Indraswati, D., Sutisna, D., Nursaptini, \& Anar, A. P. (2020). Pendidikan IPS Menjawab Tantangan Abad 21: Sebuah Kritik Atas Praktik Pembelajaran IPS di Sekolah Dasar dikuasai siswa dalam menghadapi abad 21 hanyalah kemampuan terhadap teknologi dan. Jurnal Pendidikan Ilmu

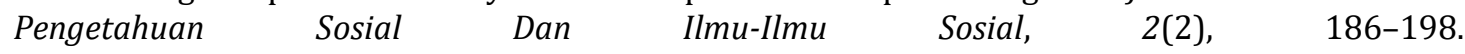
https://doi.org/http://dx.doi.org/10.19105/ejpis.v2i2.3868.

Wulandari, A. P., \& Renda, N. T. (2020). Hubungan Antara Pola Asuh Orang Tua dengan Motivasi Belajar Matematika Siswa. Mimbar Ilmu, 25(2), 90. https://doi.org/10.23887/mi.v25i2.26068.

Yuliantika, S. (2017). Analisis Faktor-Faktor Yang Mempengaruhi Disiplin Belajar Siswa Kelas X, Xi, Dan Xii Di Sma Bhakti Yasa Singaraja Tahun Pelajaran 2016/2017. Jurnal Pendidikan Ekonomi Undiksha, 9(1), 35. https://doi.org/10.23887/jjpe.v9i1.19987. 